\title{
Implication Of Protection And Fulfillment Of Women's Political Rights Through Affirmative Action Policy
}

\author{
Nur Asikin \\ Faculty of Law, Borneo University \\ Jln. Amal Lama No.1, Tarakan Timur, Kota Tarakan, Indonesia \\ Tel.: +62-811-5307023 Fax:+62-551-2052558,E-mail :asikin_thalib@yahoo.com
}

\begin{abstract}
One group of citizens who because of the conditions require special treatment is women. Without special treatment or affirmative action, women will not be able to access the protection and fulfillment of their constitutional rights because of the differences and distinctions generated and perpetuated by the structure of patriarchal society. The protection and fulfillment of constitutional rights without special treatment will tend to maintain discrimination against women and unable to achieve justice
\end{abstract}

Keywords: discrimination and affirmative

\section{INTRODUCTION}

Efforts to increase women's representation become so important to give women justice for their political rights. The need for political education with due regard to gender equality and justice. In relation to gender equality, in Law No. 2 of 2011 on Amendment to Law Number 2 Year 2008 on Political Parties (hereinafter referred to as Law Number 2 Year 2011), and Law Number 8 Year 2012 on General Election of DPR, DPRD and DPD Members (hereinafter referred to as Law Number 8 Year 2012) mandates the need for political education with due regard to equity and gender equality. It is thus aimed at raising awareness of the rights and obligations of every Indonesian citizen. ${ }^{1}$

The issue of women's representation in the political field is actually in the 2009 election is expected to realize equality and justice for women in politics by applying affirmative action policy both in Law Number 2 Year $2011^{2}$ and Law Number 8 Year of $2012^{3}$ which

\footnotetext{
${ }^{1}$ Astrid Anugrah, Keterwakilan Perempuan Dalam Politik, Jakarta, Ctk. II. Pancuran Alam 2009, p.1

2" Particularly Article 2 Paragraph (2) stating that "The establishment and establishment of Political Parties referred to in paragraph (1) includes 30\% (thirty percent) of women representation"

${ }^{3}$ Article 53 paragraph (2) of the contents "In the list of prospective candidates as referred to in paragraph (1), the list of prospective candidates as referred to in Article 52 shall contain at least $30 \%$ (thirty percent) of women's representation" in every 3 (three) candidates there will be at least 1 (one) female candidate.
} 
provides special treatment with a $30 \%$ quota for women as a first step to encourage women's representation in the political field in an equitable and just direction. Unfortunately, the affirmative action policy is "disallowed" indirectly through the decision of the Constitutional Court, Number 22-24 / PUU-VI / 2008 which annulled the enactment of Article 214 Letter a, b, c, d and e where the provisions of Article 214 These letters a, b, $\mathrm{c}, \mathrm{d}$ and e are essentially canceling the use of the serial number in the determination of the elected legislative candidates but by virtue of the majority vote so that with the cancellation automatically zipper system based on the sequential number to determine the position of the woman cannot be executed. On the journey it is a verdict is a debate both by the pros and cons of this decision. However, if we think the special treatment for women by giving a quota of $30 \%$ is not said to be pampering for women themselves, it should be understood that the political conditions in Indonesia is still very masculine which

"(but in practice the system known as zipper system or zigzag can not be executed because the decision of the Court Decision Number 22-24 / PUU-VI / 2008 revoking Article 214 Letter a, b, c, d, and e where the provisions of Article 214 Letter a, b, c, d and e are essentially using serial number system, then because it is canceled in automatic zipper system can not be executed even if not cancel Article 55). gives rise to gender bias ${ }^{4}$ for women and it is understandable that this particular policy for women is not contrary to the democratic essence and it can even be said that this policy is an ideological action in the realization of gender equality and justice $^{5}$ in Indonesia.

The controversy of the Constitutional Court's decision (hereinafter referred to MK) Number 22-24 / PUU-VI / 2008 which annulled Article 214 Letter a, b, c, d and e of Law Number 10 Year 2008 regarding General Election of DPR, DPD, and DPRD where the article regulates the determination of candidates for legislative members based on serial number then the Constitutional Court decides that the elected candidates are based on the majority vote. The Court reasoned that the decision was based on the spirit of democracy stipulated in the 1945 Constitution and the reference through Law Number 7 of 1984 concerning the ratification of the Convention concerning the elimination of all forms of discrimination against women or known as CEDAW (Convention on the Elimination

\footnotetext{
4 Mansour Fakih, Analisis Gender dan Transformasi Sosial, Bias Gender sama dengan Ketidakadilan Gender baik bagi kaum laki-laki maupun kaum perempuan dimana ketidakadilan gender merupakan sistem dan struktur dimana baik kaum lakilaki dan perempuan menjadi korban dari sistem tersebut, Pustaka Pelajar, Yogyakarta, 2008, p. 12

${ }^{5}$ Ibid, p. 8
} 
of All Forms of Discrimination against Women). This verdict has drawn much debate in various circles, especially from women and gender activists in Indonesia who stated that the Constitutional Court's decision to curb the existence of affirmative action policy in which it is one of the efforts to realize gender equality and justice in the concept of democracy. But on the other hand there are also parties who feel this to be a positive breakthrough to shift the dominance oligarchy in political parties that have been determined by the leadership of political parties in which the policy of the leadership of political parties often disappoint the cadres of political parties by placing them on small sequential numbers.

Regardless of the controversy that occurred since the presence of the verdict, a matter to be seen carefully is the loss of Indonesian women's constitutional rights in which the ruling affects the existence of the affirmative action regulated in Law Number 8 Year 2012 regarding Legislative Election as outlined in Article 55 paragraph (2) which provides an opportunity for women with zipper system to sit in parliament becomes useless because it cannot be executed. Whereas the provision has a strong foundation in Article $28 \mathrm{H}$ paragraph (2) ${ }^{6}$

Of the 1945 Constitution. The article is in addition to a noble intention to improve the degree and dignity of Indonesian women, as well as the recognition of the Indonesian nation, the ongoing inequalities between men and women. Therefore, a temporary special action or policy is required, with a $30 \%$ quota, in order for Indonesian women to have equal access to equality and justice. ${ }^{7}$ The next problem is the representation of women in parliament will be reduced by the closing of opportunities to implement affirmative action in the 2009 General Election, it should be noted together that there are several reasons why women's quota is felt important to do special treatment in the last Election 2009. The reason set forth by Maria Farida Indrati in his quotation from Hanna Pitkin, The Concept of Representation, 1967, follows: ${ }^{8}$

1. Women represent half of the population and have the right to

\footnotetext{
6 Pasal $28 \mathrm{H}$ ayat (2) yang isinya, yaitu: "Setiap orang berhak mendapat kemudahan dan perlakuan khusus untuk memperoleh kesempatan dan manfaat yang sama guna mencapai persamaan dan keadilan."

${ }^{7}$ Lihat Suara Terbanyak dan Nasib

Perempuan,

http://agussetiawan007.wordpress.com/2009/01/27/suaraterbanyak-dan-nasib perempuan/, diakses tanggal 5 September 2013

${ }^{8}$ Maria Farida Indriati (Dissenting Point) Dalam Putusan Mahkamah Konstitusi Nomor 2224/PUU-VI/2008 p. 110
} 
half of the seats ("justice argument");

2. Women have different experiences of men (biologically and socially) being represented ("experience argument"). In line with this argument women can enter positions of power because they will be bound in different politics;

3. Women and men have a conflict of interest so that men can not represent women ("interest group argument");

4. Female politicians represent important role models encouraging other women to follow. The core idea behind the electoral gender quota is to recruit women into political institutions and ensure that women are not isolated in political life.

Of the four reasons actually if we want to recognize and realize that the existence of women quota becomes mandatory to realize the equality and special treatment is actually also been accommodated by the constitution. In addition to being subject to our Constitution, Indonesia as a state party that has ratified CEDAW has an obligation to implement all the principles contained in the convention into national law. One of the principles that serve as an excuse to legalize specific measures in the granting of quotas to women is to observe the provisions of Article 4 of CEDAW, whose contents are:

\begin{abstract}
"The use of temporary measures by the government to spur de facto men's and women's equality is not considered discrimination. But it should not be perpetuated because it is equivalent to maintaining different inequalities and standards. The move must be stopped immediately when the goal of equality of opportunity and action has been achieved".
\end{abstract}

The principle of the chapter is only temporary until the conditions of women reach equality with men or in other words this is called positive discrimination ${ }^{9}$ to encourage women equal to men in politics.

As an illustration of the existence of CEDAW which gives special treatment to women in obtaining civil, political, economic, social and cultural rights in Indonesia not only based on the necessity

9 Decision of the Constitutional Court Number 22-24 / PUU-VI / 2008 The grant of 30\% quota and the requirement of one woman candidate from every three candidates constitute positive discrimination in order to balance between representation of man and woman to become legislator in House of Representative, Regional, and Provincial / Regency / City House of Representatives. 
of Indonesia as state parties but also social condition of Indonesian society which is still very gender biased ${ }^{10}$. This we can realize together that in Indonesia the society is still largely thick with patriarchal culture is still difficult to accept women leaders. In addition to the reasons for their weak leadership, women are also considered to have less ability in all areas or in other words women are positioned as subordinate than men.

\section{Problems}

What is the implication of protection and fulfillment of women's political rights through affirmative action policy?

\section{DISCUSSION}

\section{Woman's Rights}

Women's Rights, which is a right owned by a woman, whether because she is a human being or as a woman, in the context of human rights law can be found arrangements in various legal system of human rights. This system includes various legal instruments and legal system implementation tools at national, regional

\footnotetext{
${ }^{10}$ Gender is an inherent trait of men and women who are socially and culturally constructed from Mansour Fakih, Gender Analysis and Social Transformation (Yogyakarta: Pustaka Pelajar, 2008), p. 8. While Gender Bias is similar to Gender Injustice both for men and women where gender inequality is a system and structure in which both men and women become victims of the system , sebagaimana dikutip dari Mansour Fakih, Analisis Gender dan Transformasi Sosial, (Yogyakarta: Pustaka Pelajar, 2008), p. 12
}

and international levels. These systems not only include recognized rights but also how to guarantee and access those rights ${ }^{11}$.

Women's Rights (HAP) can be understood as the right of a woman, because she is female. HAP arises because the Universal Declaration of Human Rights (UDHR) has not been able to accommodate the protection of women for the exercise of their rights.

Thus, Women's Rights are part of Human Rights, which can not be separated from the history of human rights development. The Human Rights of Women is the third wave of human rights, arising from the UDHR and the two conventions of International Covenant on Civil and Political Rights (ICCPR) ) and the International Covenant on Economic, Social and Cultural Rights (ICESCR) has not adequately accommodated women's basic rights, has not recognized differences between women and men and does not regulate affirmative action to vulnerable groups, including women.

In 1979, the United Nations adopted the Convention on the Elimination of All Forms of Discrimination against Women (CEDAW). CEDAW is a human rights declaration that comprehensively

${ }^{11}$ Sri Wiyanti Eddyono, Hak Asasi Perempuan dan Konvensi CEDAW, Lembaga Studi dan Advokasi Masyarakat, Materi Kursus pengacara, 2005, p. 1 
recognizes the HAP and becomes the first universal instrument to regulate HAP. Even CEDAW is considered the Bill of Right for Women which became the first universal standard governing HAP. ${ }^{12}$

In support of the implementation of CEDAW a committee was formed, the Committee on the Elimination of Discrimination against Women in 1982. Subsequently to support the committee's communication competence and performance, on May 25, 2000, the General Assembly passed Resolution 54/263 on Optional Protocol to the Convention on the Elimination of All Forms of Discrimination against Women which became effective on 22 December $2000^{13}$

Actually long before CEDAW Born, the international community has given a firm recognition of the protection of women's rights. The Charter of the United Nations signed on 26 June 1945 in San Francisco and became the juridical basis for the birth of the United Nations, in its preamble to declare faith in fundamental human rights, in the dignity and worth of the human person, in the equal right of men and women ${ }^{14}$.

\footnotetext{
${ }^{12}$ Majda El-Muhtaj...Op.Cit., p. 237

${ }^{13}$ Ibid, p. 238

${ }^{14}$ www.un.org
}

At the international level of the international human rights legal system, the recognition of women's rights as a human right is rooted in the General Declaration of Human Rights, which emerged in 1947 and adopted by the General Assembly of the United Nations on December 10, 1948. This Declaration (hereinafter referred to as Of the Universal Declaration of Human Rights), is the beginning of codification on the standard of recognition of human rights in which women's rights are included. This declaration is recognized as a common standard for all societies and all nations to strive for the progress of human dignity ${ }^{15}$. The 1948 Universal Declaration of Human Rights recognized by universal human rights standards has emphasized the importance of universal protection and fulfillment of universal human rights. In the context of Indonesia for example, women's human rights arrangements can be found in the 1945 Constitution, Criminal Code, Civil Code, Law Number 1 of 1974 on Marriage, Human Rights Court Law and various other regulations. Enforcement is done by state institutions and law enforcement. One of the main sources is Law No. 7 of 1984 on the

\footnotetext{
${ }^{15}$ Women, Law and Development, Hak Asasi Manusia Kaum Perempuan, Langkah demi langkah, terjemahan dan terbitan LBH APIK, Jakarta, 2001, p. 13
} 
ratification of the Convention on the Elimination of All Forms of Discrimination against Women. The law clearly adopts the Convention on the Elimination of All Forms of Discrimination against Women ${ }^{16}$.

One group of citizens who because of the conditions require special treatment is women. Without special treatment, women will not be able to access the protection and fulfillment of their constitutional rights because of the differences and distinctions generated and perpetuated by the structure of patriarchal society. The protection and fulfillment of constitutional rights without special treatment will tend to maintain discrimination against women and unable to achieve justice ${ }^{17}$.

The importance of eliminating discrimination against women through special treatment to obtain equal opportunities and benefits in order to achieve equality and equity that has also been recognized internationally. In fact it is manifested in its own convention (Convention on the Elimination of All Forms of Discrimination against Women / CEDAW). The elimination of

\footnotetext{
${ }^{16}$ Sri Wiyanti Eddyono, Op. Cit., p. 2
}

${ }^{17}$ Jimly Assihiddiqie, Menuju Negara Hukum Yang Demokratis, Secretariat Jenderal Dan Kepaniteraan Mahkamah Konstitusi Republic Indonesia, Jakarta, 2008, p. 564 discrimination through advancement towards gender equality is even formulated as a basic need for the promotion of human rights in the Millennium Development Goals (MDGs). It is realized in eight areas of efforts to achieve the MDGs, among which are promoting gender equality and improving women's empowerment and improving maternal health. The formulation is based on the fact that women represent half of the world's population of about 70 percent of the world's poor are women ${ }^{18}$.

At the national level, efforts to eliminate discrimination against women and gender achievement have been made even at the implementation level still require serious work and attention ${ }^{19}$.

\section{Women's Representation}

According to Joni Lovenduski, there are three mechanisms that can be taken to increase women's representation in parliament: firstly, Rhetoric Strategies with the accommodation of women in political party platforms and campaigns; second, positive discrimination or quota strategy (Strategies of positive discrimination the quota) through the allocation of seats to women as legislative

\footnotetext{
${ }^{18}$ Ibid.

${ }^{19}$ Ibid.
} 
candidates; the third affirmative action strategy such as determining the target of how many women as legislative candidates. $^{20}$

That the view of Joni Lavenduski calls for two forms of women's representation in parliament, namely through political parties in campaigns and through parliamentary quotas. These two things are meant by the writer related to Lovenduski's view of the representation of quota through process (campaign) and representation through quota of parliament. Sekaitan with views Joni Lavenduski as Miriam Budiarjo that today's political representation is the system of representation that is considered the most reasonable ${ }^{21}$.

The consideration of women's representation in the implementation of political moment in Indonesia is based on the consideration of women's problems that are not so small in Indonesia, thus in order to obtain answers or solutions from women's issues, at least by women. Similarly, the issue of children and injustice against women both in the public and domesticated.

\footnotetext{
${ }^{20}$ Joni Lovenduski, Introduction: The Dynamic of gender and party" in gender and parti politics Joni Lovenduski and pippa Noris (eds.) 8 (London Thousan oaks, New delhiL sage publications, 1993

${ }^{21}$ Miriam Budiarjo, Dasar-dasar ilmu Politik edrevisi .PT gramedia Pustaka Utama. Jakarta, 2008 p. 176
}

In every election for example, the proportion of women's political representation is getting better even though it can not be separated from the ups and downs. In the period 1955-1960 recorded the number of female parliament members as much as 6.3 percent, and the constituents 1956-1959 recorded 5.1 percent. In the period 1971-1977 women in the Parliament as much as 7.8 percent, the period $1977-1982$ as much as 6.3 percent, the 1982-1987 period of 8.5 percent, the period $1987-1992$ by 13 percent, the period 1992-1997 as many as 12.5 percent, the period $1997-1999$ as much as 10.8 percent, the period 1999-2004 by 9 percent, and the period 2004-2009 as much as 11.1 percent. While in this period, 2009-2014, the representation of women has reached 18.05 percent, ie a number of 101 people from 560 people the number of members of the House. This is the greatest percentage of Indonesia's political history. In 2014-2019 the pemiu is very unfortunate because the representation of women in Parliament decreased from $18 \%$ to $17.32 \%$. This means that from 560 men only 96 people are members of the House of Representatives women.

Although it has not yet reached the $30 \%$ target of women's representation in parliament, this reality raises optimism 
that Indonesian women can play a greater role in the political arena. With the limited representation, it does not mean that women in the DPR do not play a significant role. With a continuously improved capacity, women in parliament will be more involved and can influence decision-making more and more so as to determine each policy that is formulated.

Why women's representation becomes so unbalanced. This is due to several factors namely :22

1. The socio-cultural value of male preference

2. Division of labor by gender in agrarian-traditional societies

3. The image of women as the meek

4. Religious teachings interpreted narrowly and partially

5. Lack of government political will

6. Disadvantages in individual quality and political regeneration

The importance of women's participation in politics because the real one understands and understands women's issues and conditions is the woman herself. With the inclusion of women in the political sphere

22. Siti Hariti Sastriyani, Gender And Politic, Yogyakarta, Diterbitkan Atas Kerjasama Pusat Studi Wanita Univ. Gajah Mada Dan Penerbit Tiara Wacana, 2009, p. 166 (public) is expected to have an effect on the resulting policy products, especially those directly related to women's lives. Moreover, the Indonesian government has ratified conventions related to women's political participation, namely the Convention on the Rights of Women Politics (The Convention on Political Rights for Women) .That is, the Indonesian government is obliged to implement every part and article of the convention maximally.Because basically women's political rights in the broad sense is integral and inseparable from human rights, and vice versa, the right human rights is a fundamental aspect of various democratic frameworks. ${ }^{23}$

To achieve substantive justice in the process of women's representation, it is necessary to have impartial justice in one particular group, but the existence of equality of all parties in the political process.

According to the writer's opinion that the understanding of democracy in Indonesia is the existence of the space of individual and group political rights, is just legal arrangement to be used as reference / guidance in politics.

\footnotetext{
23 Demos: Riset Putaran I mengenai Masalah-masalah dan Pilihan-pilihan Demokratisasi diIndonesia. 2003.
} 
The representation of women with minimum quota of $30 \%$ of women in the legislature at all levels of legislative bodies is $30 \%$ of DPR RI members, $30 \%$ of members of Provincial DPRD and 30\% of members at Regency / City DPRD level. Regulation on minimum quota of $30 \%$ at each level The competition center is between individual women. This means that whoever the most votes of women throughout Indonesia will sit up to be split up $30 \%$, so the voice that competes is the voice between women throughout Indonesia.

When, the voice of women has reached $30 \%$, then the next vote will be competed with the male voice under the applicable legal provisions. So if based on legal provisions, then it could be women will be higher then the women seat will increase more than $30 \%$.

The idea of women's representation is essentially to give women political rights in the management of the state. So that sekaitan with women issues will be solved by women themselves. At least the argument that women's issues will be solved by women themselves. While men will take care of the state of affairs in general, even if it can help women, then it is part of participation.
Entering the era of independence began to have progress in the fulfillment of women's political rights as citizens. In the deliberations of the Election Law which began in 1948 there was hardly any refusal to use the right to vote and be elected for women. This can be said of significant progress, since in some countries including Western Europe and North America, women's political rights have not been fully granted.

In an effort to increase the number of women in parliament, the first view emphasizes the improvement of the quality of women legislative candidates so that they can compete in free elections. In this case political education and political training for women is crucial. In other words, the key to political equality is the empowerment of women. The second view, however, emphasizes the creation of electoral systems and mechanisms that facilitate women to enter parliament. Therefore special policies are needed for women legislative candidates in order to have greater chances of being elected in the electoral mechanism. This particular policy is only temporary in nature efforts to catch up with women in political talks. If equal conditions are met, the policy can be eliminated, since women are already in equal condition to engage in free political 
competition. The essence of politics of this difference is affirmative action policy. Implementing temporary special measures may trigger conflicts, but only temporarily. It is a necessity of women far behind men in political access, with special interim measures of equal opportunity, quality, role and toleration of differences in political access for women. This temporary special action policy is temporary. The implementation of this policy is certainly on the terms of the ability of the target to find affirmations, such as women in the political arena. Certainly not ordinary women who are encouraged as policy makers, but women who have the perspective, awareness and a sense of partiality to advance the people who are left behind. And can make a meaningful contribution to society and country.

Massive movements that encourage affirmative or temporary special policies for women's representation in politics with a minimum $30 \%$ quota system in the Political Act begin to manifest their results in the form of state policies after the enactment of Law No. 12 of 2003 on General Elections in one the article gives a call for election participants to nominate $30 \%$ of women as members of the legislature. This policy is not yet imperative, but it is at least a new breeze for the women's movement in parliament and outside parliament to campaign for the importance of women's representation of at least $30 \%$ in policy institutions. This policy was accompanied by encouragement of women activists to enter into parties considered to be able to voice the problems of poverty, health, democracy including women's issues.

Representation of women in a very lame parliament is not caused by differences in sex (nature or destiny), especially on gender differences (social construction). This is a perception and social construction that closed the access of women to more active in politics. As a gender issue (social construction), the representativeness of women in parliament can be changed and enhanced, despite the need for long process and waiting. ${ }^{24}$

\section{Aspirational Women for representation in Parliament}

Throughout the history of Indonesia and the various movements of women's aspirations in several countries in realizing women's representation in legislative institutions, it is the aspiration of women who have been running long enough. It means that there is no instant interest of women to enter parliament solely because of a "jealousy", but it is

$24 \quad$ Ibid. p. 169 
based on several approaches both philosophically, juridical, politically and sociologically.

Quantitatively, women have the power to be granted political rights regulated in the provisions of legislation. Likewise qualitatively, that not a few women who plunge in the world of politics and able to provide the best service for a change of Nation and State, the ability of women is not only in local level of Regency / City but also at provincial and central level.

General election is also one of the most fundamental means of distributing citizens' human rights. Therefore, in the framework of the implementation of the human rights of the citizens is a must for the government to ensure the implementation of elections in accordance with predetermined governance schedule Relation to aspirate as the views of RH Taylor , ${ }^{25}$ that:

"Democratic elections require a number of conditions, namely: a) recognition of universal suffrage; b) the discretion to establish a shelter for the plurality of voters' aspirations; c) the existence of

${ }^{25} \mathrm{RH}$ Taylor, "Election and Politics in Southeast Asia," dalam RH Taylor, 1996.ed, The Politics of election in Southeast Asia, Canbridge: Woodrow Wilson Center Press and Canbrige University Press, p. 2 political recruitment mechanism for open candidates of the people's representatives; d) the freedom of voters to discuss and make choices; e) the existence of discretion for election participants to compete in a healthy manner; f) an honest counting of votes; g) the existence of bureaucratic neutrality; and, h) the existence of an independent election organizer"

Women's aspirations for women's representation should be doctrinally based on values, norms, legal principles, and legal principles. While the constitution is to refer to the provisions of the Constitution and the applicable legislation. Representation of women based on the constitution and doctrine, as a consequence that the state of Indonesia is a State of law, which all forms of its arrangement is based on applicable law provisions.

So the affirmative action with the aspirations of women should be arranged in such a way as to give birth to legal certainty. The aspiration of women to obtain $30 \%$ quota is to be based on legal provisions.

If the legal provisions are inadequate then it is necessary to amend 
the legal provisions, which in principle can accommodate the interests of women.

Various matters provisions relate to the aspirations in realizing women's vizacies, namely, firstly, the recognition of human rights, the aspirations of the community on women's rights, that all parties must recognize the aspirations of women for the purpose of fighting for women's own rights; second, the mechanism of recruitment which is implemented by a political party is to be open to provide space to women in filling the availability of the city that has been determined. The mechanism of determination is to be based on the legal provisions and the provisions of the articles of association of the political party's household budget, in order to create transparency by political parties. Third, that as a form of popular sovereignty there is freedom for the electorate to make his choice, the election process is carried out without any foundation, intentions, or pressure to constituents. Fourth, that women candidates have the same freedom as other candidates to compete in a healthy manner or health treatment is the flexibility for election participants to compete both men and women. Fifth, the vote count is based on legal provisions with the formulation that should meet the $30 \%$ quota of women's representation in the legislature.

Simply put, the aspirations of women related to affirmative action are the provision of representation of $30 \%$ of women in legislative bodies both at the Central, Provincial, and District level. The existence of regulations regulating the matter with the quota of $30 \%$ of women in the form of a special law, as well as changes to the law already exist.

\section{Woman's Participation}

The issue of women's participation is still very lacking in their involvement in women's institutions. However, some women's pressure groups accept the $30 \%$ representation of women in legislative bodies. Nevertheless, even though Law Number 8 Year 2012 on legislative elections regulates at least $30 \%$ of women in the list of legislative members.

This means that the participation of women in formal institutions is still very far from expectations, it can happen because of the Law made in a hurry and change. Thus, even if women are fought for women's participation, it is also necessary to encourage fellow women in their involvement in the legislature. This is as expressed by Hemas. "It turned out that 
the Act has not been able to give effect to women. Women's political participation in formal political institutions is far from ideal, "because the act of affirmative for women's struggle in the legislature through representation of candidates is incapable of encouraging women to sit legislatively in line with expectations. Thus affirmative action should be given specialization for women to $30 \%$ enter the legislature.

Affirmative action issues related to women's participation are the challenges that must be paid attention to: firstly, the policy that government policy has the power to grant $30 \%$ quota of women in parliament by providing women's space for access to information at governmentrelated government level. Second, the commitment of women to participate in government is very important. Because the issue of representation of women groups is a problem that was born from the will and desire of women for the problems that arise in the community. So by giving the quota of $30 \%$ of women in parliament, it is necessary for the commitment. Because without the commitment of women, the community tends not to have confidence in

\section{CONCLUSION}

Third, the quality that besides the force of law, the strength of regulation in realizing women's representation in the women. Third, the quality that besides the force of law, the strength of regulation in realizing women's representation in the legislature. So the most important thing must also be had is the quality of women in the nomination process. Because the position of legislative office is a position that needs competence because it is related to the function of legislative design, supervisory function, budgeting function, and aspirational function.

Participation with the quality of legislative candidates from women's groups there are some groups that must participate in developing the quality of women, political parties and government. These three groups have an important role in encouraging women's quality to be able to inflate the mandate of legislative members. $30 \%$ of women then the group should provide the strengthening of the quality of women because the minimum quota affirmative action in parliament is a quota that is definitely women enter the parliament.

legislature. So the most important thing must be the quality of women in the nomination process. Because the position of legislative office is a position that needs 
competence because it is related to the function of legislative design, supervisory function, budgeting function, and aspirational function.

Participation with the quality of legislative candidates from women's groups is a party that participates in developing the quality of women, political parties and government. These three

\section{BIBLIOGRAPHY}

Demos: Riset Putaran I mengenai Masalahmasalah dan Pilihan-pilihan Demokratisasi diIndonesia. 2003.

Jimly Assihiddiqie, Menuju Negara Hukum Yang Demokratis, Secretariat Jenderal Dan Kepaniteraan Mahkamah Konstitusi Republic Indonesia, Jakarta, 2008

Joni Lovenduski, Introduction: The Dynamic of gender and party" in gender and parti politics Joni Lovenduski and pippa Noris (eds.) 8 (London Thousan oaks, New delhiL sage publications, 1993

Mansour Fakih, Analisis Gender dan Transformasi Sosial, , Pustaka Pelajar, Yogyakarta, 2008

Maria Farida Indriati (Dissenting Point) Dalam Putusan Mahkamah Konstitusi Nomor 22-24/PUU$\mathrm{VI} / 2008$

Miriam Budiarjo, Dasar-dasar ilmu Politik ed-revisi .PT gramedia Pustaka Utama. Jakarta, 2008

Putusan Mahkamah Konstitusi Nomor 2224/PUU-VI/2008

RH Taylor, "Election and Politics in Southeast Asia," dalam RH Taylor, 1996.ed, The Politics of election in Southeast Asia, Canbridge groups have an important role in encouraging women's quality to be able to inflate the mandate of legislative members. $30 \%$ of women then the group should provide the strengthening of the quality of women because the minimum quota affirmative action in parliament is a quota that is definitely women enter the parliament.

Siti Hariti Sastriyani, Gender And Politic, Yogyakarta, Diterbitkan Atas Kerjasama Pusat Studi Wanita Univ. Gajah Mada Dan Penerbit Tiara Wacana, 2009

Sri Wiyanti Eddyono, Hak Asasi Perempuan dan Konvensi $\boldsymbol{C E D A W}$, Lembaga Studi dan Advokasi Masyarakat, Materi Kursus pengacara, 2005

Suara Terbanyak dan Nasib Perempuan, http://agussetiawan007.wordpress.c om/2009/01/27/suara-terbanyakdan-nasib perempuan/, diakses tanggal 5 September 2013

Women, Law and Development, Hak Asasi Manusia Kaum Perempuan, Langkah demi langkah, terjemahan dan terbitan LBH APIK, Jakarta, 2001

www.un.org 